\title{
Age Determination of the Hazel Grouse Based on Skull Pneumatization
}

\author{
Hee-Young ChaE and Yuzo FuJimaki \\ Laboratory of Wildlife Ecology, Obihiro University of \\ Agriculture and Veterinary Medicine, Inada, Obihiro 080, Japan
}

\begin{abstract}
Skull pneumatization was examined in relation to actual age for 37 known-age Hazel Grouse Bonasa bonasia raised in an aviary. Although pneumatization advanced with increasing age, unpneumatized areas (UPA) were present on the cranial roof even in old adult birds. Five indices indicating the size of UPA, i. e. 1) length of UPA, 2) width of UPA, 3) length of UPA $\times$ width of UPA, 4) length of UPA/total length of skull, and 5) width of UPA/greatest width of skull, were examined. Of the five indices, the fifth index was a reliable criterion for separating firstyear birds of $4-8$ months of age from older birds of $\geqq 15$ months of age; the index value was 0.158 to 0.306 for the former and 0.063 to 0.145 for the latter. The value for separation is 0.15 . This criterion was adopted to determine the age of Hazel Grouse killed during hunting seasons from 1 October to 31 January in Hokkaido, Japan. Of 49 birds examined, firstyear and older birds accounted for 77 and $23 \%$ respectively.
\end{abstract}

Key words: Hazel Grouse, Bonasa bonasia, Skull, Pneumatization, Age determination

Age determination of wildlife is an important aspect of research in wildlife ecology. In the Hazel Grouse Bonasa bonasia, age may be determined by the number of white bars on the 9th primary (GAIDAR \& ZHITKOv 1974), the width of the beige border at the tip of the innermost primary (STENMAN \& HELMINEN 1974), or the layered structure of the mandible (MITANI \& FUJIMAKI 1992). However, the spotting pattern on the 9th primary is not always a reliable criterion for age determination of the species because there are geographical variations in the spotting pattern of primary feathers (BonCZAR \& SWENSON 1992). MiTÁNI \& FUJIMAKI's (1992) method requires complicated techniques and more time than other methods.

Skull pneumatization of the Hazel Grouse advances with increasing age, although the skull did not completly pneumatize and non-aerated areas were always present on the cranial roof even in old adult birds (WINKLER 1979). During the hunting season from 1 October to 31 January in Hokkaido, Japan, first-year birds are 4 to 7 months of age, and others are more than 15 months of age, because chicks hatch in early and mid-June (HAGA \& TAKAMATA 1986). The objectives of this study is to examine the reliability of the size of unpneumatized areas (UPA) on the cranial roof as a criterion for separating birds less than 8 months of age from those 15 months of age and more and to determine the age of birds killed during the hunting seasons in Hokkaido. 


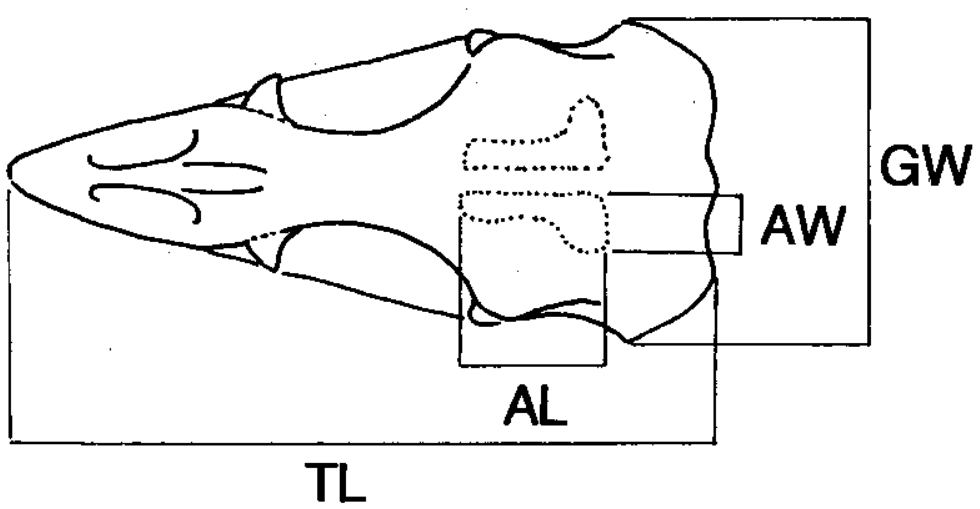

Fig. 1. Measurements of the Hazel Grouse skull. TL=total length, $\mathrm{GW}=$ greatest width, $\mathrm{AL}=$ length of unpneumatized area, $\mathrm{AW}=$ width of unpneumatized area.

\section{MATERIALS AND METHODS}

Samples consisted of 37 known-age birds raised in an aviary and 49 wild birds killed during the hunting seasons of 1991/92 and 1992/93 in Hokkaido. The captive birds were raised under the same temperatures as natural conditions and were fed on a diet for young birds (SASAOKA \& FuJimaki 1990) until mid-September of the first year and then on a diet composed of pet food, hen feed, fish meal and vegetables (FUJIMAKI et al. 1994). The ages of captive birds ranged from 1 month to 5 years.

All skulls were thoroughly cleaned and were bleached in $10 \%$ hydrogen peroxide liquid for 5 to 10 minutes and then dried in the shade. Four cranial measurements were taken to the nearest length of $0.1 \mathrm{~mm}$ with digital calipers for each specimen: total length (TL) and greatest width (GW) of the skull, and lengths (AL) and greatest width (AW) of the right and left UPA (Fig. 1). When measurements of UPA were made, each skull was illuminated from bottom. Skulls have separate UPA on either side of the pneumatizd areas adjacent to the median line. Although there were no skulls showing conspicuous asymmetry in non-aerated areas, the means of two AL and two AW were designated as the representative value of $\mathrm{AL}$ and $A W$ respectively. The reliability of five indices indicating the size of UPA, AL, $\mathrm{AW}, \mathrm{AL} \times \mathrm{AW}, \mathrm{AL} / \mathrm{TL}$ and $\mathrm{AW} / \mathrm{GW}$, were examined in relation to actual age.

Mann-Whitney's U or Kruskal-Wallis tests was used to compare means between different age classes. Throughout the paper, means are presented with their standard deviations.

\section{RESULTS}

Data for both sexes were combined because of the small numbers of birds, 2 to 5 , in each class. The mean TL and GW increased significantly from $42.3 \pm 2.5 \mathrm{~mm}$ $(n=5)$ and $19.8 \pm 1.1 \mathrm{~mm}$ at 1 month of age to $51.7 \pm 0.7 \mathrm{~mm}(n=6)$ and $23.1 \pm 1$. 
$1 \mathrm{~mm}$ at $4-5$ months of age, respectively $(H=11.142$ for $\mathrm{TL}, H=11.328$ for $\mathrm{GW}$, $P<0.01$ ). The mean TL and GW at $4-5$ months of age did not differ from those at 8-10 (51.8 \pm 1.4 and $23.0 \pm 1.4, \mathrm{n}=6)$ and $\geqq 12$ months of age (52.4 \pm 0.8 and 23 . $9 \pm 0.5, \mathrm{n}=11, H=2.755$ for TL, $H=4.835$ for $\mathrm{GW}, P>0.2)$. These facts indicate that TL and GW of young birds attained adult size by 4 months of age.

The mean AL was $9.1 \pm 0.7 \mathrm{~mm}(n=5)$ at 1 month of age, and it decreased gradually after that with fairly large individual variations to $5.9 \pm 1.7 \mathrm{~mm}(n=5)$ at $\geqq 24$ months of age (Fig. 2). The mean AL/TL also showed a similar decrease with age, changing from $0.217 \pm 0.025(n=5)$ at 1 month of age to $0.112 \pm 0.032$ $(n=5)$ at $\geqq 24$ months of age (Fig. 3). The mean $\mathrm{AL} \times \mathrm{AW}$ decreased from 71.5 $\pm 7.4(n=5)$ at 1 month of age to $31.6 \pm 6.8(n=4)$ at 5 months of age, and then decreased slightly to $17.0 \pm 7.6(n=5)$ at $\geqq 24$ months of age (Fig. 2). The mean

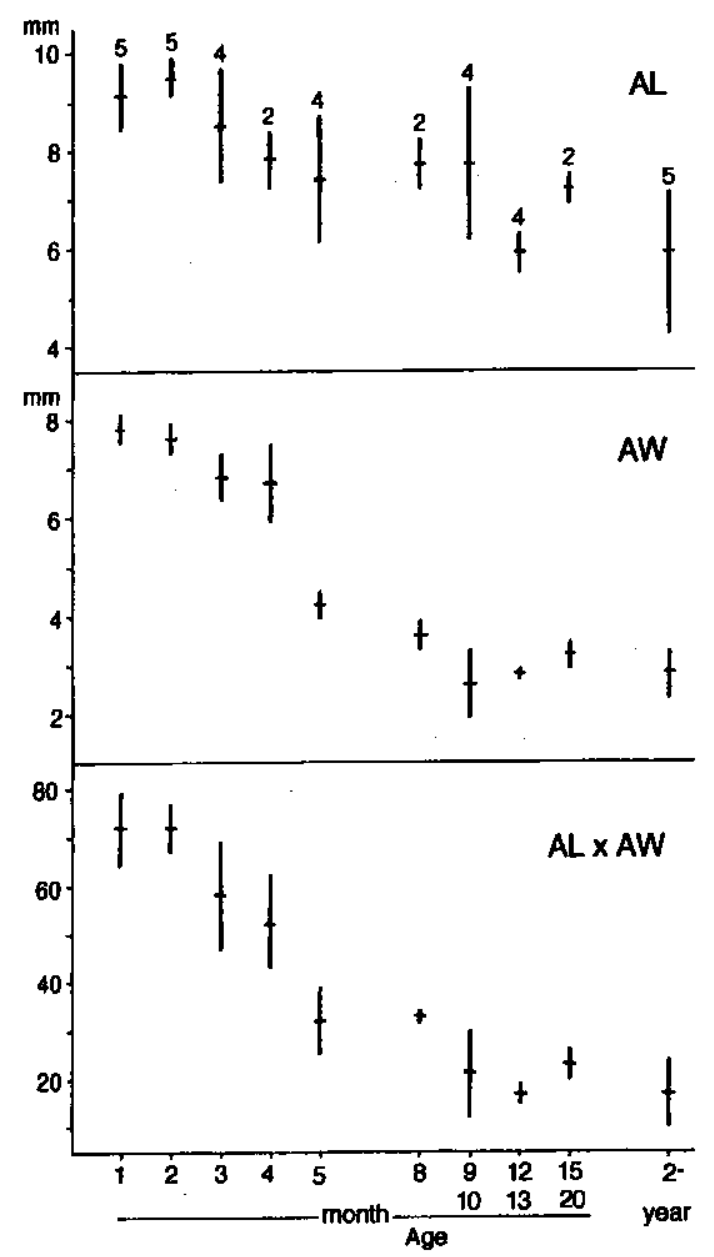

Fig. 2. Variations of three indices ( $\mathrm{AL}, \mathrm{AW}$, and $\mathrm{AL} \times \mathrm{AW}$ ) indicating the size of unpneumatized area in relation to actual age. Sample sizes for each age class are indicated above the vertical bars. 
$\mathrm{AW}$ and $\mathrm{AW} / \mathrm{GW}$ decreased from $7.8 \pm 0.3 \mathrm{~mm}(\mathrm{n}=5)$ and $0.395 \pm 0.031(\mathrm{n}=5)$ respectively at 1 month of age to $2.6 \pm 0.7 \mathrm{~mm}(n=5)$ and $0.115 \pm 0.032(n=5)$ at 9-10 months of age, after which the values did not show apparent change (Figs. 2 and 3 ).

Comparing five indices between two age classes, $4-8$ and $\geqq 15$ months of age, because birds at these age are killed during hunting seasons in Hokkaido, there were siginificant diffrences in $\mathrm{AW}, \mathrm{AL} \times \mathrm{AW}$ and $\mathrm{AW} / \mathrm{GW}$ between two age classes (Table 1). However, AW ranged from 3.4 to $7.2 \mathrm{~mm}$ in the former age class and from 2.0 to $3.4 \mathrm{~mm}$ in the latter, overlapping partly between two age classes.

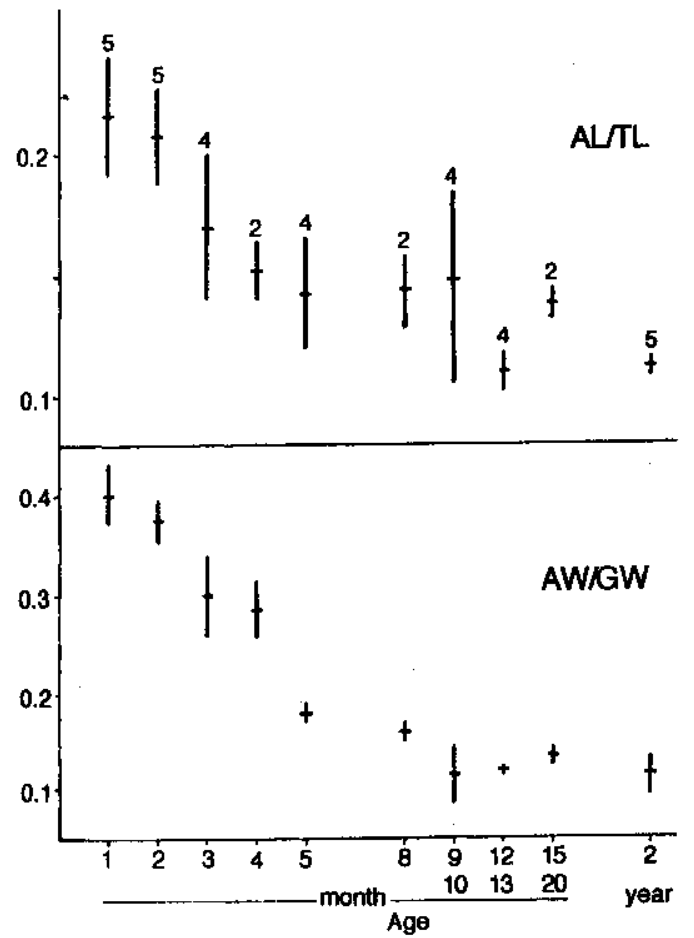

Fig. 3. Variations of two indices ( $\mathrm{AL} / \mathrm{TL}$ and $\mathrm{AW} / \mathrm{GW}$ ) indicating the size of unpneumatized area in relation to actual age. Sample sizes for each age class are indicated above the vertical bars.

Table 1. Comparison of five indices of unpneumatized areas on cranial roof between two age classes of Hazel Grouse

\begin{tabular}{|c|c|c|c|c|c|}
\hline \multirow[b]{2}{*}{ Indices } & & \multicolumn{3}{|c|}{ Age in months } & \\
\hline & & $4-8$ & & $\geqq 15$ & \\
\hline $\mathrm{AL}$ & $\mathrm{n}=8$ & $7.6 \pm 0.9$ & $\mathrm{n}=7$ & $6.2 \pm 1.7$ & $U=15.0, P>0.05$ \\
\hline $\mathrm{AW}$ & $\mathrm{n}=8$ & $4.7 \pm 1.3$ & $\mathrm{n}=7$ & $2.9 \pm 0.5$ & $U=2.0, \quad P<0.01$ \\
\hline $\mathrm{AL} \times \mathrm{AW}$ & $n=8$ & $35.8 \pm 11.9$ & $\mathrm{n}=7$ & $18.7 \pm 7.7$ & $U=4.0, \quad P<0.01$ \\
\hline $\mathrm{AL} / \mathrm{TL}$ & $\mathrm{n}=8$ & $0.145 \pm 0.017$ & $\mathrm{n}=7$ & $0.120 \pm 0.032$ & $U=16.0, P>0.05$ \\
\hline $\mathrm{AW} / \mathrm{GW}$ & $n=8$ & $0.203 \pm 0.054$ & $\mathrm{n}=7$ & $0.121 \pm 0.023$ & $U=0, \quad P<0.01$ \\
\hline
\end{tabular}




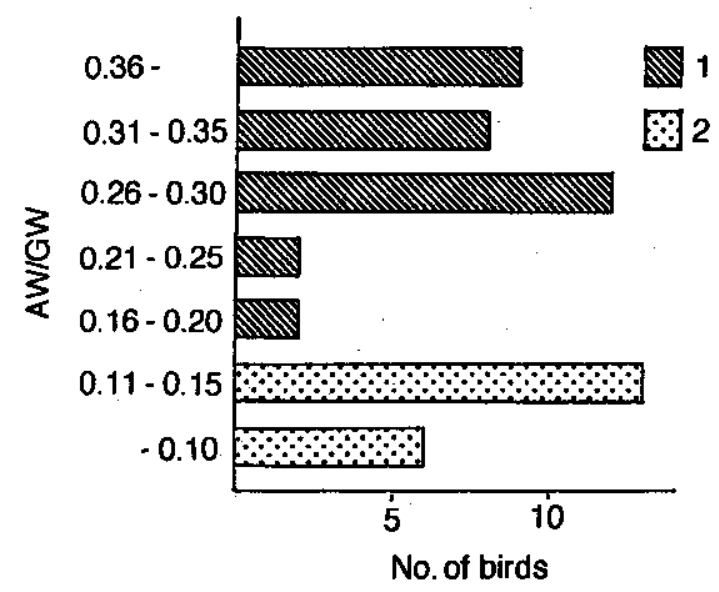

Fig. 4. UPA-size distribution of the Hazel Grouse killed between October and January, 1991/92 and 1992/93, in.Hokkaido, Japan. $1=$ birds less than 8 months old, $2=$ birds over 14 months old.

$\mathrm{AL} \times \mathrm{AW}$ value also overlapped between two age classes, ranging from 12.1 to 14.9 in the former and 7.1 to 15.4 in the latter. On the other hand, $\mathrm{AW} / \mathrm{GW}$ values did not overlap between two age classes, ranging from 0.158 to 0.306 in the former and from 0.063 to 0.145 in the latter. Of five indices, $A W / G W$ is the most reliable criterion for separating young birds from older ones, the value for separation being 0.15 .

AW/GW of 49 wild birds killed between 1 October and 31 January ranged from 0.07 to 0.418 . When 0.15 was used as a criterion, 33 birds (67\%) were designated as first-year birds, having $0.197-0.418$ of $\mathrm{AW} / \mathrm{GW}$, and 16 birds were older birds, having $0.07-0.148$ of $\mathrm{AW} / \mathrm{GW}$. $\mathrm{AW} / \mathrm{GW}$ values were in the ranges of $0.26-0.41$ for the great majority of first-year birds and $0.11-0.15$ for older ones (Fig. 4).

\section{DISCUSSION}

The Hazel Grouse grows up adults size by the end of September (SEMENovTyAN- SHANSKII 1959, GAVRIN 1969, SASAOKA et al. 1990). Skull size also attains adult one by this time. However, the unpneumatized area on the cranial roof continues to decrease in size by 9 to 10 months of age. If the birds less than 8 months of age are distinguished from older ones by the indices examined, these indices are accepted as a criterion for sorting out the first-year birds killed during hunting seasons from older ones.

Five indices showing the size of UPA were examined in relation to actual age. Of them, AL and AL/TL were not suitable for separating the first-year birds because these values decreased gradually up to 24 months of age. AL $\times$ AW and AW values decreased to 9 months of age and then remained rather constant, and there were significant differences in the means for birds of $4-8$ and $\geqq 15$ months of age. However, these two indices were also not appropriate for separating the first-year birds because of overlap in values between two age classes. Of the five indices, the $\mathrm{AW} / \mathrm{GW}$ value can be used as a reliable criterion in determining the age of the 
Hazel Grouse.

Acknowledgment: We wish to thank Dr. J. E. Swenson, Norwegian Institute for Nature Research, for his kindness in reading and correcting the earlier draft of this manuscript. We also wish to thank the members of the Hokkaido Hunters Association who have helped in gathering of specimens. This study was performed as a part of wildlife management system project of Hokkaido Prefecture.

\section{LITERATURE CITED}

BonCZAR, Z. \& SWENSON, J. E., 1992. Geographic variation in spotting patterns on hazel grouse Bonasa bonasia primary feathers: consequences for age determination. Ornis Fennica 69: 193-197.

Fujimaki, Y., MiYaZAWA, Y. \& SaSAOKA, K., 1994. Diet of hazel grouse and diet intake in captivity. Jap. J. Ornithol. 43: 49-59. (In Japanese with English summary)

GAIDAR, A. A. \& ZHTTKov, B. M., 1974. K metodike opredeleniya vozrasta ryabchika (Method of determining age of hazel grouse). Ekologiya 1974, (3): 102-103. (In Russian).

Gavrin, V. F., 1969. Ekologiya ryabchika v Belovezhskoi pushche (Ecology of hazel grouse in Belovezhsk forest). Gosdarstvennoe Zapovedno-okhotnich'e khozyaistvo "Belovezhskaya pushcha" 3: 146-172. (In Russian).

HAGA, R. \& TAKamata, S., 1986. Ecology and breeding biology of the hazel grouse Tetrastes bonasia in captivity 1 . Breeding, artificial insemination, and rearing control. Tori 34: 105-125. (In Japanese with English summary)

Mitani, A. \& FujIMAKI, Y., 1992. Age determination of the hazel grouse and carrion crow based on the layered structure of the mandible. Jap. J. Ornithol. 40: 109-111.

SASAOKA, K. \& FUJIMAKI, Y., 1990. Diet of Tetrastes bonasia chicks and diet consumption in captivity. Jap. J. Ornithol. 39: 25-32. (In Japanese with English summary)

Semenov-Tyan-ShanskI, 0., 1959. Ekologiya teterevinykh ptits (Ecology of tetraonid bidrs). Laplandskogo Gosudarstvennogo Zapovednika 5: 1-318. (In Russian).

Stenman, O. \& Helminen, M., 1974. Aging method for hazel grouse (Tetrastes bonasia) based on wings. Suomen Riista 25: 90-96. (In Finnish with English summary)

WinkLrR, R., 1979. Pneumatisation des Schadeldachs der Vogel. Orn. Beob. 76: 49-118. 
た. 育㵶期間を通して日中の給慨にとくに集中した時間帯は見られなかった. 育雅後期のヒナに対す る慨動物をビデオ装置による記録 $(n=802)$ から同定したところ，鳞翅目幼虫があっとも多く，つい でクモ類, 双翅目成虫の順となった．

巣内および巣立ち後のヒナについて, 体重およびふ蹠長について計測を行ったところ, ふ蹠長の発 達はかなり早く, 巣立ち日ですでに成鳥の $98.9 \%$ に達していた。

ヤブサメの育蓶期には突然つがい雄（ $\alpha$ 雄）とは異なる雄（ $\beta$ もしくは $\gamma$ 雄）が出現することが OHARA \& YAMAGISHI（1984，1985）によってすでに報告されているが，筆者らの育雅期を観察で きた25巣のうち, 12巣 (48.1\%) であやはり $\beta$ もしくは $\gamma$ 雄の出現が確認された。 $\alpha$ 雄は一般に育雏 期間にはさえずらず，七ナへの給餌のみを行ったが， $\beta$ 雄は育雊前期に出現すると，七ナの巣立ちま で巣の近くでさかんにさえずった．また時折り，つがい以外の侵入個体を攻撃したり，七ナへ給慨を するのあ観察された.さらに，つがい雄への攻撃を行うあのあ見られた. しかし， $\beta$ 雄の行動に対し てつがいはほとんど直接的な攻撃もしくは防衛行動を示さなかった． $\alpha$ 雄は七ナの巣立ちと同時に, 再びソングエリア内をさかんにさえずりながら, 巣立ちビナへの給餌を行い, 頻繁に雌とともに行動 した.これは $\alpha$ 雄による 2 回目の繁殖への受精可能期を迎えた雌の防衛行動であると思われた. 繁殖 初期から観察できた28巣のうち，一羽であ巣立ちできた巣は21（75.0\%）とかなり繁殖成功率は高かっ た.

自分の巣が抱卵中に，巣とかなり離れた場所で捕獲された雄が11例記録された．これは，遠出をす ることにより侵入先での雌とつがい外交尾を成功させるための戦略と思われたが, 侵入した縄張り内 での雌が受精可能期にあるあのはわずかに $36.4 \%$ だっった。したがって, 遠出をする雄は, 自分の巣

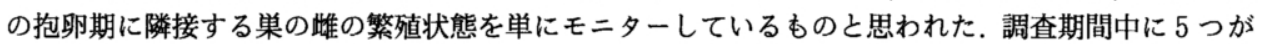
いが, 同じペアーで一繁殖期内に 2 回の繁殖を成功させたが, 1 回目と異なるつがい相手を見つけた 例はなかった. 育雅期間中につがい以外の雄が頻繁に現れるにあかかわわらず，一繁殖期間内におけ る離婚率がかなり低いことは，1回目の繁殖を成功させたことが, 雌に同じ雄を 2 回目あ選択させた あのと思われた. また, 本調查地におけるヤブサメの高い繁殖成功率は, 餌量が豊富なことと捕食率 が低いことが原因と思われた. 今後は繁殖成功率の低下した場合における, 繁殖システムに変化が起 きるかどうかについて追求する必要がある.

\section{頭骨含気化状況にもとづくエゾライチョウの齢査定}

(Age Determination of Hazel Grouse Based on Skull

Pneumatization. 45: 17-22)

蔡 熙 永・藤 巻 裕 蔵

\section{帯広畜産大学畜産環境科学科野生動物管理学研究室}

エゾライチョウBonasa bonasia の齢查定法としては初列風切羽 9 番目の暗色縞の数, 初列風 切羽 1 番目の先端部のベージュ色の幅, 下額骨に見られる層構造の数による方法がある. しかし, 前

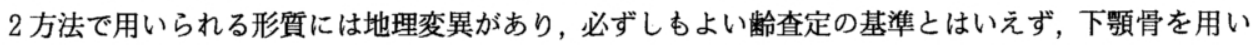
る方法は手数がかかる.エゾライチョウの頭頂の未含気化部は成鳥になっても消失することはなく, 成長するとともに小さくなる．この部分の大きさが齢查定の基準として有効かどうかを, 飼育で齢の 明らかな37羽（1 か月齢～ 5 年齢）を用いて検討し，その結果を1991/92，1992/93の狩椫期に捕獲さ れた49羽に適用してみた.

計測部位は頭骨全長 (TL), 頭骨最大幅 $(\mathrm{GW})$, 未含気化部の長さ（AL）之幅（AW）の 4 か所 
である. 未含気化部の大きさの指標として, AL, AW, ALXAW, AL/TL, AW/GWの 5 つの值を 用い,これらと実際の齢との関連を調べた。

$\mathrm{TL}$ と GW の平均値は 1 か月齢のそれぞれ $42.3 \pm 2.5$ ( $n=5$, 平均値 $\pm \mathrm{SD}$, 以下同様), $19.8 \pm$ $1.1 \mathrm{~mm}$ から 4-5 か月跲の $51.7 \pm 0.7(n=6), 23.1 \pm 1.1 \mathrm{~mm}$ に増加したが, その後は 8-10 か月 齢で $51.8 \pm 1.4$ と $23.0 \pm 1.4 \mathrm{~mm}(n=6), \geqq 12$ 加齢で $52.4 \pm 0.8$ と $23.9 \pm 0.5 \mathrm{~mm} \quad(n=11)$ で, 頭骨の大きさは 4 か月龄で成鳥の大きさに達した.

$\mathrm{AL}$ の平均值は 1 か月齡で $9.1 \pm 0.7 \mathrm{~mm}$ で, その後徐々に減少し, $\geqq 24$ 朋齢で $5.9 \pm 1.7 \mathrm{~mm}$ となった. $\mathrm{AL} / \mathrm{TL}$ の平均値も 1 加月齢の $0.217 \pm 0.025$ から $\geqq 24$ 加齢の $0.112 \pm 0.032 \%$ に変化し, $\mathrm{AL}$ と同じような減少のしかたを示した. ALXAW の平均值は 1 か月齢の $71.5 \pm 7.4(n=5)$ から 5 か月齢の $31.6 \pm 6.8(n=4)$ に減少したが，その後は $\geqq 24$ 跧の $17.0 \pm 7.6(n=5)$ に徐々に減 少した. $\mathrm{AW}$ と $\mathrm{AL} / \mathrm{GW}$ の平均値は 1 か月齢のそれぞれ $7.8 \pm 0.3 \mathrm{~mm}, 0.395 \pm 0.031 \%$ から 9 10か月齢の $2.6 \pm 0.7 \mathrm{~mm}, 0.115 \pm 0.032$ に変化し, それ以後には大きな変化は見られなかった.

エゾライチョウは 6 月に躬化するが, 北海道におけるエゾライチョウの狩弾期は10月 1 日〜 1 月 31 日なので, 狩猟で捕獲される個体で, 1 年未満のあのでは $4 \sim 7$ か月齢, 1 年以上のものはすでに 15

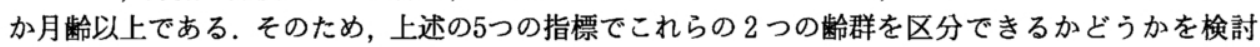

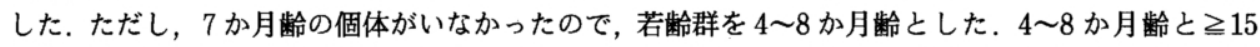
か月齢との間で5つの指標を比較すると, AW, ALXAW, AW/GW の 3 指標の平均值には有意な 差が認められた. しかし, $\mathrm{AW}$ と $\mathrm{AL} \times \mathrm{AW}$ は 2 つの蹌群の間でそれぞれ一部重複するため, 指標と しては不適である. $\mathrm{AW} / \mathrm{GW}$ の平均値は 2 つの齢群の間で有意な差が認められ, 範囲も若龄群で 0.158 0.306, 成鳥群で $0.063 \sim 0.145$ で重複しなかった. これらの結果から，4-8 か月齢とミ15か月齢 とを区分すのに適切な指標は, $\mathrm{AW} / \mathrm{GW}$ で, 区分する基準値は $0.15 \%$ とできる.

この方法を，狩猟で捕獲された 49 羽に適用したところ，33羽（67\%）が 1 年未満, 16 羽（33\%）が 1 年以上の個体であった.

\title{
1 シーズンに多回繁殖するヒメアマツバメの産卵タイミング
}

(Timing of Laying in Multiple-brooded Little Swifts

Apus affinis. $45: 23-30$ )

\author{
堀 田昌 伸* \\ 大阪市立大学理学部生物学教室 $\quad$ T558 大阪市住吉区杉本3-3-138
}

温帯に生息する多くの鳥類種で, より早く営巣する個体ほど 1 年に多く繁殖を試み, 多くのヒナを 育てるということが知られている. 日本中部に周年生息するヒメアマッバメ（Apus affinis）は, 4 月から12月にかけて 2 回から 3 回繁殖する.ヒメアマッバメは気象条件に著しく影響を受ける飛翔 性昆虫を餉としている．ヒメアマツバメの産卵日と産卵以前の気象条件との関係について調查した。

調查は, 1986年から1989年まで, 静岡県清水市有度山にあるコロニーで行った. 営巣ぺア数は, 28 (1986), 30 (1987)，38 (1988)，49（1989）であった. 1981年よりほとんどすべての成鳥と幼鳥に足 環を着け, 1985年よりすべての巣内ビナに足環を着けた. 初列風切や尾羽における換羽や摩耗の程度 から, 足環のない個体の年齢を查定した. 成鳥は 2 歳と 3 歳以上に分けた. 気象データは, 調查コロ

\footnotetext{
*現所属 : 長野県立自然保護研究所 $\quad$ T380 長野市若里298 県立長野図書館内
} 